\title{
Young People, Antisocial Behavior and Unemployment: Toward a Trans-Disciplinary Analysis of Criminalization
}

\author{
Ross Fergusson $^{1}$ (i)
}

Accepted: 17 December 2021 / Published online: 10 February 2022

(c) The Author(s) 2022

\begin{abstract}
This article considers the diverse use of the concept of criminalization in criminological and socio-legal analyses, the meanings attached to it, and the differentiated modes and manifestations of the processes of criminalization in the United Kingdom. It draws together the contributions of both disciplines (criminology and socio-legal studies) to extend understanding and theorization of the concept of criminalization, and it applies them to antisocial behavior legislation and unemployment policy concerning young people. The article identifies three distinctive modes of criminalization-illegalizing, impelling and imputing - through which the criminalization of targeted young people is realized. The article argues that criminological assessments and theorizations of criminalization and assessments developed in socio-legal studies have largely developed independently. It considers the prospects for a trans-disciplinary approach to criminalization in theory and in practice that would attempt to build on complementarities between the critiques developed by both disciplines, and it identifies possibilities for synthesizing their insights.
\end{abstract}

\section{Introduction}

The use of the concept of criminalization in relation to young people in the United Kingdom (UK) over recent decades has been complex, ambiguous and sometimes unstable in its diverse applications, interpretations, meanings, and perceived effects. For example, in England and Wales, the 1997-2010 New Labour governments' adoption of the Risk Factor Prevention Paradigm (Farrington 2007; West and Farrington 1973) is said to have "legitimized excessive criminalization" until the government was replaced by the Conservative-Liberal-Democrat coalition, whose policies resulted in "substantial decriminalization of a large section of the population of children and young people" (Gray and Smith 2019: 2, 5). Paradoxically, the comparatively benign New Labour welfare regime had an ostensibly more criminalizing effect despite its inequality-reducing measures, while the harsh austerity regime of the Conservative-led coalition following the 2008 Global Financial Crisis (GFC) reduced criminalization despite the regime's notorious intensification of socio-economic inequalities. Nevertheless, Gray and Smith's (2019: 14) conclusion that "structural inequalities and unequal power

Ross Fergusson

Ross.fergusson@open.ac.uk

1 The Open University, Walton Hall, Milton Keynes MK7 6AA, UK 
dynamics [remain] at the root of crime and criminalization" has been widely endorsed by criminologists. Recent analysis in the United States (US) of the ways in which deep inequalities among young people are reproduced also draws heavily on the concept. Selman and colleagues (2019: 5) argue that "while policymakers have begun to reform the most blatant forms of criminalization and exclusion, there are several 'shadow measures' that facilitate carceral entanglement in less obvious ways." In addition, they note that "many young people are categorized as being higher risk, in large part, because of . . . where they grow up, and by the number of times they . . . have had contact with overt criminalization and 'shadow carceral measures"' (Selman et al. 2019: 9).

Both analyses maintain well-supported convictions about the concept of criminalization. Certainly, the processes of criminalization in the UK have assumed more covert and/or sophisticated forms that nevertheless amplify and extend pre-existing inequalities. While many criminologists accept this view, it does little to persuade skeptics of the insights provided by the concept of criminalization or of its analytical application in policy and practice. Its proliferating use draws attention to the need for further development of theories of criminalization in criminology and socio-legal studies. The two disciplines, however, rarely "pool" their analyses, and the critical potential of the concept is underexploited. While the observations that follow have no pretensions to achieving synthesis across criminological and socio-legal theorizations, they draw attention to the prospects for doing so. In addition, they endeavor to highlight the potential for both disciplines to realize their complementary capacities to push back against the criminalization of young people, especially in the contexts of the socio-economic effects of the GFC and the current global pandemic, and the risks of increasing criminalization that they bear as international and intra-national inequalities proliferate.

This article begins with an overview of the ways in which the concept of criminalization has evolved over five decades in criminological analysis and theory, outlining diverse examples of criminalization directed at vulnerable, excluded socio-economic groups that are most frequently vilified and victimized. From here, the article explores the more recent-and separate-critique of criminalization provided by socio-legal studies, focusing on distortions of statutory law and miscarriages of justice. The following part considers specific manifestations of criminalization that shape young people's supposedly antisocial behaviors (ASB) and their exclusion from labor markets, using both disciplines' analyses. Drawing on these, the penultimate part identifies three distinctive modes of criminalization-illegalizing, impelling and imputing - through which the criminalization of targeted young people is realized, again focusing on ASB and unemployment policies. The final part explores the distinctions and complementarities between the two disciplines' approaches, offering reflections on what they might conjointly contribute to synthesis and trans-disciplinary theorization of criminalization across these policy contexts, as well as on what this means for challenging criminalization "in practice" and the prospective benefits of doing so.

\section{Criminology and Criminalization: Origins, Definitions, Theories}

If we examine its etymological origins, in 1584, "to criminalize" meant "to accuse," from the Middle French verb criminaliser. In English, the first recorded usage, in 1694, meant "to pass a case from the civil to the criminal jurisdiction" (Oxford English Dictionary Online 2019). Current definitions of "to criminalize" in the Oxford English Dictionary $(O E D)$ include: 
To turn (a person) into a criminal, especially by making his or her activities illegal (dated 1647).

and

To turn (activity) into a criminal offence by making it illegal (dated 1832).

This second definition is unremarkable: its meaning is self-evident. But the first definition is open to wider interpretation. Criminalizing a person by turning that person into a criminal is also unremarkable if it refers only to the process of prosecuting him or her for a statutory offense. But "to turn" also suggests potential "redefinition"-signaling a transition from the status of citizen toward a liminal status as criminal, by means other than prosecution. This peculiarity is reinforced by the qualifying clause: "especially by making his or her activities illegal." This may mean that new laws may be put in place expressly for the purpose of making certain "activities" liable to prosecution. Alternatively, "especially" may mean that the person concerned could be "turned into a criminal" by means other than making his or her actions illegal-perhaps by persecution, stigmatization or victimization. Or it could mean wrongful indictment for crimes the person did not commit but which stand as proxies for disapproved actions or behaviors which cannot be prosecuted as criminal. This latter interpretation creates the possibility of using civil offenses to address actions which do not contravene statutory law, but which have become the subject of public disapprobation. Furthermore, it might imply a deliberate or cynical attempt to make activities illegal by the imposition of restraints on activities using civil orders - the breach of which is subject to criminal sanction.

These definitions make no distinction between justifiable and unjustifiable criminalization. This omission is fundamental in obstructing clear critical analysis of the concept and its consequences. Nothing in $O E D$ definitions implies that any process of criminalization lacks social and political legitimacy. In current everyday parlance, "to criminalize" generally refers to the act of prosecuting an individual or making an activity illegal. But in much academic discourse, the concept of criminalization carries an implicit meaning that a class of actions has been designated as criminal in ways that are unjustifiable or inappropriate. Here, the word and the concept imply an act of "making criminal" that is at least inappropriate, and potentially unjust or lacking legal legitimacy. It is important to be alert to uncritical uses of the word and their prospectively insidious effects.

The most succinct contemporary criminological definition of criminalization is probably Chadwick and Scraton's (2013: 103): "the institutionalized processes through which certain behaviors are labelled as 'crimes' and 'outlawed'." If "labelled" were substituted with "designated," this would be likely to meet wide acceptance as an uncontroversial definition. Even the authors' qualifying sentence, "[i]t reflects the state's decision to regulate, control and punish selectively" (Chadwick and Scraton 2013: 102), is anodyne if it is accepted that all acts of prosecution are inherently selective, insofar as other equally proscribe-able acts go unpunished.

The concept of criminalization gained broad currency among criminologists during the 1990s, drawing on a much longer provenance in social reaction theory, labeling theory and deviancy theory. Muncie's (2008: 14) account makes reference to the founding work of sociologists, such as Erikson (1962) and Lemert (1951), and he, Muncie, offers the following observation:

Social reaction and labelling [theories] marked the first step in understanding why and how only certain troubling behaviors and acts are subject to criminalization and 
why a host of other more serious social harms . . . appear to be routinely practiced with impunity ... These insights still retain their original power to challenge the politics of law and order and expose the processes of selective criminalization.

Other longstanding theorizations of criminalization come from some classic criminological texts. In the US, Platt's (1977) founding analyses captured the oppressive proto-criminalizing propensities of the so-called child-saving movement, its anxieties about delinquency, and its promotion of repressive "treatment" regimes. So, too, did Quinney's (1977) account, which identified capitalism's dependence on reserve armies of labor to manage the ebb and flow of demand according to business cycles and economic variables; on the criminal justice system to manage the strains and conflicts that arise from the exclusion from labor markets of oppressed populations; and on the resultant extremes of poverty and associated expanding prison populations. Neither text uses the concept "criminalization," but it is central to Reiman and Leighton's (1979/2017) "Pyrrhic defeat theory" and its analysis of why and how the mechanisms of the US criminal justice system discriminate most heavily against poor and racially identified groups.

More recently, Carlen's (1996: 123) influential studies of young people's homelessness and workless poverty in England in the mid-1990s recession captured their vilification and criminalization-especially with her key concept of "asymmetries of citizenship," as characterized by "the so-called underclass and much denied 'over-class'." Others have put forward the cogent argument that "the corollaries between child poverty, social and economic inequality, youth crime, criminalization and state intervention are undeniable" (Goldson and Muncie 2006: 99). Most recently, corollaries of this kind have been palpable in police management of young people's worldwide protests during the GFC (Newburn 2015; Somavia 2012; Tyler 2013). An extensive contemporary UK literature has also explored associations between class, race and criminalization among young people (Goodey 2001; Scraton 2007; Squires 2008; Squires and Lea 2012; Webster 1997). Many of these studies have portrayed the visceral misery and oppression of criminalization as it bears on young people struggling to attain independent adulthood. It remains important in what follows to think beyond structural causes and flawed policies of criminalization to recognize the lived experiences of "criminalization-in-practice" as described by some of these studies.

\section{Socio-Legal Studies and Criminalization: A Critical Review}

Critical analysis of criminalization among academic lawyers is well-developed, albeit along different lines. Fifty years ago, their preferred term was "over-criminalization," which was employed to emphasize the tendency to create more, unnecessary and harmful laws (closer to the second $O E D$ definition quoted above). While this term should invoke the concept of the "under-criminalization" of actors whose neglect and harms, themselves, contribute to the processes of "over-criminalization" (Tombs 2005), "over-criminalization" continues to provide a sound basis for arguing that it is inefficient as well as unjust to use criminal law for non-criminal acts, and that it also thereby handicaps legitimate enforcement of appropriately recognized offenses. As Kadish (1967: 157) argued, "[p]ressures to criminalize persistently block practical assessments of what the criminal law is good for (and what it is not)." His analysis focused on (ab)uses of vagrancy laws as proxies for other offenses, such as begging, being unemployed, loitering, and sleeping outdoors. These laws, he argued, are "used by police as a basis for arresting, searching, questioning or detaining persons (who otherwise could not legally be subjected to such interventions) because of suspicion that 
they have committed or may commit a crime" (Kadish 1967: 168). This is closer to the first $O E D$ definition, whereby a person, rather than an activity, is "turned into" a criminal.

In contrast, Husak's (2008) critical engagement with criminalization began with objections to an absence of theorization. It focused on the need for philosophical clarity about the rationale for punishing actions selectively. Husak (2008: 3) argued that an excessive number of actions are punished unjustly "for conduct that should not have been criminalized at all." One objection concerns the futility of laws which are not widely known because of their number, their complexity, or because of inadequate notice of legal obligations: "Law exists largely to guide behavior, but this objective is undermined in our climate of over-criminalization" (Husak 2008: 11). His second objection was that "over-criminalization" brings the law into disrepute because "punishments deter partly through the stigmatizing effect of criminal conviction ... [but] as the scope of criminal liability expands, stigma is depleted and deterrence most likely is eroded" (Husak 2008: 12). Husak's third objection concerned the absence of a clear referent for the principle of proportionality. As he explained, this obstructs consistent relationships between the definition of what is criminalized, the punishment attached to it, and the harms caused to others: "[over-criminalization] makes disproportionate punishments all but inevitable" (Husak 2008: 15).

Husak identified two groups of constraints as key elements of a theory of criminalization that should limit the authority of the state. He described the first as internal constraints because they are derived from criminal law: "the non-trivial harm or evil constraint, the wrongfulness constraint, the desert constraint and the burden of proof constraint" (Husak 2008: 255 (emphases in original)). He described these as constraints that should be included in a theory of criminalization designed to limit the proliferation of offenses of risk prevention. The second group concerned three "external" requirements-to reduce a substantial risk, to decrease the likelihood of "the ultimate harm," and to prevent the risk of "the consummate harm"-all of these to be used "only when defendants act culpably" (Husak 2008: 22).

Tomlin's (2013) analysis generated other considerations of justness. They concern defining individuals as criminal (the second $O E D$ definition) and making illegal acts that were previously legal (the first definition). The centerpiece of Tomlin's (2013: 65) argument was that if we accept the moral force of the Presumption of Innocence Principle,

we should be as concerned about punishing [people] for doing things that cannot appropriately be punished as we are about punishing them for what they did not do. Therefore, the same epistemic standards should be applied to decisions concerning criminalization as to conviction.

Tomlin (2013: 57) expanded on this by drawing out the consequences of putatively unwarranted acts of criminalization:

Given that, like the jury, the legislator has to make such an important decision that will not only lead to people being punished, but to people having moral reasons to avoid certain kinds of conduct, surely we should expect her to be as careful, and err in the same way, as the juror? The reason that we place the high epistemic standard on the jury is that we ask them to make a very important decision that will hugely affect people's lives, and that we will take to be ... authoritative. The legislature's decisions are much the same.

Tomlin $(2013: 61,65)$ argued that legislation and judgments following trial by jury should maintain the same epistemic standards, such that "conduct, like persons, must be considered innocent until proven guilty," and that "we could still question whether the gap that 
currently exists between the caution we expect of juries and the comparatively lax epistemic standards we expect of legislatures should continue."

Tomlin's (2013) implication is that poor legislation results in unjust punishment of intended or actual conduct. In such cases, if a jury were to find a defendant guilty of similar actions, it would probably be deemed a miscarriage of justice. Taken together, these three analyses highlight multiple absences: a well-founded theory of criminalization; consistent standards for determining which previously un-proscribed actions have already been unjustly criminalized; and adequate protections against "turning" people into criminals and specific conducts into criminal offenses.

\section{Manifestations of Criminalization}

Although criminology and socio-legal studies have contributed to theorizing criminalization, there is no agreed-upon basis for determining standards for creating new offenses. A focus on practices might involve observing the conduct of professionals that results in individuals being convicted of crimes that should not exist or do not apply. A focus on outcomes might involve studies of case law to assess failings resulting from poor legislation. But both would be exceedingly difficult to attempt empirically without clear parameters. This part therefore proposes such parameters by considering two policy contexts within which recent attempts to criminalize young people appear to have advanced.

\section{Young People, Antisocial Behavior and Criminalization}

As noted earlier, contemporary manifestations of the criminalization of behaviors deemed antisocial originated in the UK's New Labour governments. The original strategy to address disorderly behavior stressed the benefits of anticipating minor behaviors deemed indicative of criminality, and of using risk assessment and early intervention techniques (West and Farrington 1973). The Crime and Disorder Act 1998 introduced the Antisocial Behaviour Order (ASBO) as a civil offense-to be issued for behavior that "caused or was likely to cause harassment, alarm or distress" (Sect. 1(1)(a) (emphasis added)). ASBOs applied as civil offenses for two years. In the event of breaches of their court-ordered terms, the breach, itself, escalated the offense to criminal status. The Antisocial Behaviour Act 2003 extended enforcement powers and imposed parenting contracts on under-sixteenyear-olds whose behavior was deemed disorderly, proto-criminal or antisocial. By 2013, almost 25,000 ASBOs had been issued, and two-thirds of recipients had breached the terms of their ASBO. Half of cases of breach resulted in custodial sentences (Muncie 2021).

This high level of custodial sentencing prompted revision of ASB legislation. The 2010 Conservative-Liberal Democrat coalition government replaced ASBOs with early intervention measures to minimize the numbers of people who might receive ASBOs. Paradoxically, in 2013, the coalition's Anti-social Behaviour, Crime and Policing (ABC\&P) Bill nevertheless proposed to lower the ASB threshold to "nuisance and annoyance" and simplify and de-formalize its prosecution (see below). 


\section{Young People, Unemployment and Criminalization}

The relationship between the labor market, unemployment and crime, including among young people, has been reviewed extensively in the criminological literature, and the GFC lent it renewed pertinence (Barnes 1895; Box 1983; Carmichael and Ward 2000; Currie 1996; Fergusson 2013). By 2012, UK youth unemployment (YU) reached new heights. Twenty-two percent of young people aged sixteen to twenty-four years were unemployed (36\% among sixteen- to seventeen-year-olds). The UK had the fifth highest proportion of young people who were Not in Education, Employment or Training (NEET) in the Organisation for Economic Co-operation and Development (OECD). The Social Mobility and Child Poverty Commission (2014: 113) reported that "the recession hit young adults harder and for longer than others in the labor market, and the recovery has benefitted them least." A number of prominent bodies (e.g., International Labor Organization 2013; National Centre for Social Research 2011) warned that the levels of frustration and resentment triggered by unemployment had been evident in public discontent and social unrest. Facing an upward trend in YU that threatened to breach its "NEET" targets, the government's Education and Skills Act (ESA) 2008 required sixteen- to seventeen-year-olds to participate in education or training if they were registered as unemployed, with escalating penalties culminating in court orders and custodial sentences for persistent non-compliance (see below).

\section{Three Modes of Criminalization}

Policies and legislation on ASB and YU in England and Wales indicate that that processes of criminalization manifest themselves in three distinctive modes.

\section{The Illegalizing Mode of Criminalization}

This mode reflects the second $O E D$ definition: "making an activity illegal." The Crime and Disorder Act 1998 epitomizes covert criminalization using ASB legislation and was the object of trenchant criticism from criminologists (see, e.g., Crawford 2009; Muncie 2021). Among socio-legal scholars, Ashworth and Zender (2010) stress the Crime and Disorder Act's hybrid capacity to make civil prevention orders the subjects of criminal sanctions. "Two-step criminalization" permits civil orders to side-step the standards for criminal action, despite the fact that civil tests are by no means reliable equivalents of the tests applied in criminal prosecutions. The authors conclude that "the existing legal form of civil preventive hybrid measures can be more coercive than many criminal offenses, yet they are imposed without protections that adhere to criminalization, and that is simply unacceptable" (Ashworth and Zender 2010: 87). As Simester and Von Hirsch (2011) argue, "two-step prohibition orders" (TSPOs) amount to quasi-criminalization. They claim that criteria used to impose TSPOs "tend to include [qualifying behavior] that is not by itself either wrong or offensive or harmful, and which need not be a criminal offense....the behavior complained of need not in fact cause any distress; it is sufficient that it be "likely' so to do" (Simester and Von Hirsch 2011: 222-23). Imposing TSPOs enables courts to punish behavior that is "not otherwise criminally proscribed, and which may be harmless. Neither the triggering conduct, nor the 
prohibitory response, need satisfy the Harm Principle or Offense Principle" (Simester and Von Hirsch 2011: 230). Simester and Von Hirsch (2011: 232) conclude:

The TSP order poses foundational challenges to the preservation of rights and freedoms within a free society. ... Two-step schemes cannot be sustainable as proper forms of criminal prohibition-because the order issued is not made by a representative body and is targeted to particular persons.

Criminalization by making selected civil (mis)behaviors illegal also bears upon economically inactive young people. Non-participation in education by individuals aged thirteen and fourteen years has been the subject of legal sanction since 1870 and 1918, respectively, although parents have sole legal responsibility for school attendance. The Criminal Justice and Police Act 2001 created the offense of "aggravated truancy." But the ESA of 2008 made sixteen- and seventeen-year-olds themselves (as well as their parents) liable to prosecution for failure to participate in education, training or a prescribed alternative. The requirement for local authorities to identify young people who do not comply and to issue attendance notices, parenting contracts and orders (with potential custodial sentences on default) was annulled by the coalition government. The ESA was, nonetheless, clear evidence of the intention to bring criminal law to bear upon parents via a civil route: the potential to criminalize educationally and economically inactive sixteen- and seventeenyear-olds was available briefly, using a two-step process.

\section{The Impelling Mode of Criminalization}

The impelling mode is founded in law that predates the illegalizing mode. Whether out of ignorance of specific prohibitions (see Husak 2008) or as a result of extreme circumstances (see Kadish 1967), people sometimes act unlawfully for the purpose of meeting a basic material need. "Instrumental crimes" are typically associated with unemployment and absent welfare provision. Young non-participants may be "impelled" to offend as impecunious dependents. Fifty to seventy-five percent of homeless individuals aged sixteen to twenty-five were non-participants in work, education or training after the GFC (House of Commons 2009), and the numbers of sixteen- to twenty-four-year-olds in poverty rose rapidly (Tinson et al. 2016), along with young people sanctioned for breach of welfare conditions (Garthwaite 2016; Watts et al. 2014). Studies show clear associations between sanctions and "survival" crime (Fletcher 2016; Griggs and Evans 2010), and between changes in welfare provision and crime rates (Beckett and Western 2001; Jennings et al. 2012). Consistent with the first $O E D$ definition of criminalization, young people who offend to secure their own survival are criminalized by being impelled to offend. "Expressive crimes" of emotional resentment or anger are also well-exemplified among studies of ASB (Harradine et al. 2004). Young people charged with expressive acts of ASB were "turned into" criminals by having their actions proscribed as civil offenses, then commuted to criminal status by dint of breaching terms of an ASBO.

Instrumental and expressive crimes are often related. In the 2011 English Riots following the GFC, the mostly young rioters expressed feelings of anger, violation, and abandonment. Tyler (2013: 203-04) interprets the riots as a "zone in which young people were able to make their rage visible.” Baron's (2008: 414) study of homeless unemployed young Canadians found that "those who feel more deprived relative to others and express more monetary dissatisfaction also express more anger over their unemployment... Those who 
reported a stronger work ethic and reported looking for work more regularly also reported more anger."

These studies confound tidy distinctions between instrumental and expressive causes of crime. Criminalizing either is suggestive of Husak's (2008) critiques of over-criminalization and loss of proportionality, especially if young people identify social and economic injustices, or if an offense is motivated solely by an overwhelming need for subsistence, it invokes Tomlin's (2013) concern about punishing young people inappropriately for actions taken under duress.

\section{The Imputing Mode of Criminalization}

In this mode, no new crime is defined by legislation. Rather, young people's actions become associated with behaviors that are criminal, or that resemble crimes, or that are regarded (mistakenly) as criminal or believed to be pre-criminal or proto-criminal. This evokes the first $O E D$ definition: "to turn (a person) into a criminal, especially by making his or her activities illegal." The latter phrase also allows ways of criminalizing an individual other than by means of making the act(s) a subject of new criminal legislation-for example, by imputing.

The imputing mode has multiple versions. The first responds to fears of the projected or imagined spread of conduct that threatens behavioral codes - such as the attempt to lower the ASB threshold below "harassment, alarm or distress." In 2013, two new provisions of the government's Anti-social Behaviour, Crime and Policing (ABC\&P) Bill (UK Parliament 2013) proposed to replace ASBOs with Criminal Behaviour Orders (CBOs) and Injunctions to Prevent Nuisance and Annoyance (IPNAs). IPNAs were to be civil injunctions, served on anyone who "has engaged or threatens to engage in conduct capable of causing nuisance or annoyance to any person" (UK Parliament 2013:1 (emphasis added)), while also continuing to apply to "behavior that caused or was likely to cause harassment, alarm or distress to any person" (UK Parliament 2013: 11 (emphasis added)). These changes highlight the imputational character of IPNAs. Although the original intentions were clear, the "capable of causing" clause was subsequently withdrawn, following the House of Lords' removal of the bill's net-widening "capable of causing nuisance or annoyance" clause. This restricted IPNAs to the higher "likely to cause" threshold. For adults (those over the age of eighteen), IPNAs remained as civil injunctions under the ABC\&P Act 2014, for which the higher "beyond reasonable doubt" standard of proof was required. Breach of IPNAs is dealt with as a civil contempt of court but can nevertheless result in imprisonment for up to two years. Remarkably, for fourteen- to seventeen-year-olds, breach of the injunction can also result in up to three months detention in a secure unit. While this falls short of a criminal record, it constitutes exceptionally harsh treatment of juveniles. Young adults and juveniles alike may now be detained in secure conditions for breach of an injunction imposed for an act that is merely likely to cause harassment, alarm or distress. This designates an act that has not taken place but is perceived as a threat. In other words, guilt is imputed - that is, "attributed or assigned to" (an accused person or group), despite the absence of evidence.

A second version of imputation refers to actions that resemble criminal acts and the circumstances with which they are associated, but which are not the subject of criminal law. Such acts may be deemed criminalistic or displaying features of criminality, or may be incriminating and susceptible to indictment. They are epitomized in the actuarial methodologies of the Risk Factor Prevention Paradigm (RFPP) which shaped the Youth Justice 
Board (YJB) and Youth Offending Teams (YOTs) by claiming to predict criminality. According to this method, ASB and unemployment have strong associations with offending (Farrington 2007). One RFPP “dynamic criminogenic factor" included education, training and employment as domains for assessing risk of offending. Non-participation raised assessment scores as part of a so-called Scaled Approach, resulting in pre-emptive interventions.

The RFPP established the conditions for criminalization by imputation. As well as "being NEET," proxies for ASB ("lifestyle," "substance use") were listed risk factors (YJB 2010: 19). High scores on combinations of factors resulted in increased monitoring or surveillance. Most young people who are "NEET" never offend, but the high proportion of NEETs among young offenders easily labels them "at risk" (Godfrey et al. 2002). The Scaled Approach has been severely criticized in its own terms for targeting disadvantaged young people (Bateman 2011). Haines and Case's (2012) study concluded that the RFPP is inherently flawed and produced no consistent reductions in reconviction.

The third version of imputation derives from labeling theory. As Tyler's (2013) research shows, a key means of imputing criminal responsibility to an innocent actor is by stigmatization or naming. Whether this occurs by causing another person to "recognize" them as criminal or by regarding themselves as criminal, they become interpellated by terminology that connotes prospective indictment as "the abjects they had been told they were" (Tyler 2013: 204). Subjects thereby accommodate themselves to the discourses of their own oppression.

\section{Reflections on Modes of Criminalization}

The key intentions of the ESA 2008 and the ABC\&P Bill 2013 were unrealized. Parliament narrowly avoided making more behaviors illegal. But the most important observations brought together in the preceding survey are that the powers of the illegalizing, impelling and imputational modes of criminalization continue to mark young people who are unemployed or who are alleged to harass, alarm or distress others; and that in many instances, the propensity to label or stigmatize what cannot be prohibited is intensified because appropriate provision is not available for managing socially disapproved acts. Young people's behaviors came precariously close to legislative criminalization. Legislators acted in belated recognition that these were actions "that should not have been criminalized at all" (Husak 2008: 3). Instead, the forces of disapproval were re-channeled into criminalization by imputation. This mode best illustrates the injustices and irrationalities of attempts to manage the conduct of socially disapproved youth using criminal law and its proxies.

Viewed criminologically, these examples demonstrate claims that "social reaction and labelling [theories] marked the first step in understanding why and how only certain troubling behaviors and acts are subject to criminalization" (Muncie 2008: 14). Indeed, the core tenet of Lemert's (1951) theory is that what identifies deviancy is the social reaction it provokes, not its immediate manifestations. The determining ingredient for commuting disapproval into criminal sanction is public and/or political disapprobation. Unemployment and ASB are easily reclassified as generalized non-participation and nuisance worthy of criminal sanction.

Alongside criminologists, socio-legal scholars show that all three versions of criminalization by imputation warrant criticism for over-reliance on criminal law to perform tasks for which it is ill-suited (Kadish 1967). Using criminal intervention to manage disapproved behaviors and "risk" profiles does not meet Husak's (2008) non-trivial harm and 
wrongfulness constraints, nor his substantial risk and prevention requirements. Nor does it comply with Tomlin's (2013) Presumption of Innocence Principle.

\section{Toward a Trans-Disciplinary Analysis of Criminalization}

So far, this article has drawn together half a century of the work of criminologists and socio-legal scholars, surveying a diverse literature and evolving laws and policies concerning the trajectories of criminalization of young people. The purpose of connecting this scholarship and its related policy developments has been to deepen our understanding of the processes of criminalization during a period which has been notable for its endeavors to find sophisticated ways of governing disapproved behaviors, lifestyles and demographic groups of young people. As the previous discussion shows, the advance of modes and manifestations of criminalization in the UK has been extensive and exceptional.

In addition to its critical commentary on legal and policy developments and outcomes, this article has constructed a typology of modes of criminalization that demonstrates how two discrete disciplines have independently developed congruent, theorized critical assessments of criminalization. Any future attempt to synthesize their respective distinctive theoretical bases would provide scope for a trans-disciplinary approach that considers differences, identifies gaps, and seeks common ground between them. The theorizations in the preceding analyses have already foregrounded the disciplines' shared sense of the injustices of criminalization. But there are also important prospects for considering policies that address harms inflicted by practices of criminalization. The two disciplines, themselves, have yet to bring together their respective critical interpretations of different facets of criminalization. Criminology typically prioritizes analysis of socioeconomic and policy-related causes and harmful effects of criminalizing misuses of power and their unjust impacts on marginalized young people. In comparison, socio-legal studies highlight distortions and abuses of statutory law in the prosecution of young people to whom it should not apply, and for conduct for which it was not intended. As a result, each discipline provides much of what the other lacks for critiquing criminalization. Therefore, the analytic concurrences and congruities across both disciplines appear all the more powerful by virtue of their historically independent separate development. Their complementarities are clearly evident in their trenchant, parallel critiques of abuse and injustice. But this applies much more strongly in both disciplines' theorizations of criminalization than it does with regard to their analyses of "criminalization-in-practice."

Two examples illustrate these claims. As described above, there is self-evident complementarity between criminological critiques of ASB legislation and socio-legal critiques of two-step and hybrid criminalization. Criminologists already deplore the use of civil orders to extend police powers targeted at young people and their escalation to the status of criminal offense for breaching them. Similarly, the socio-legal critique of two-step criminalization focusses on the ways in which the lesser thresholds used for testing civil offenses are inappropriately deployed for circumnavigating the tests required for criminal prosecution, thereby overriding standard protections. Thus, some criminologists berate the net-widening powers that have accrued to address minor nuisance behavior, while some socio-legal scholars condemn judicial accommodations that allow criminal sentences by lowering thresholds for certain offenses. Both disciplines reject practices of this kind because they target easily identified vulnerable groups and subvert normal procedures and/ or due process. In other words, their analyses are independent, but their purposes are highly 
complementary. Purposively shared analyses and coordinated actions of this kind also offer prospectively more effective, deliberate, and collaborative interventions capable of stalling and blocking practices of criminalization in crime control and judicial systems alike. Critical trans-disciplinary analyses can map future pathways toward more cogent and integrative theorizations of criminalization, but both disciplines' minimal coverage of practices of criminalization requires attention.

A second example - that of survival crime resulting from poverty and deprivationraises fundamental questions within criminology about basic rights to employment, selfsustaining remuneration, and welfare (Bateman 2011; Muncie 1999, 2021; Scraton 2007; Squires 1990, 2008; Tyler 2013). These privations exemplify the impelling mode of criminalization which drives "abjects" to offend. Correspondingly, the socio-legal perspective identifies unwarranted applications of criminal law in analogous circumstances. As noted above, Kadish's (1967) investigation of prosecuting homelessness as vagrancy, Husak's (2008) analyses regarding over-criminalization, Tadros's (2008) examination of unjustifiable punishments of predictably adverse circumstances and unequal wealth, and Tomlin's (2013) study of "erroneous convictions" all present parallel socio-legal critiques. The complementarity of the two disciplines' theorizations is transparent, but once again, they are barely developed regarding criminalization-in-practice.

Although strong affinities between the disciplines' theorizations are evident in these examples, a key source of their separation — necessarily and inherently-is their epistemological differences. At the polar extremes, the gulf between the best empirical research traditions of criminology (by no means the discipline's dominant mode) and the founding jurisprudential traditions of socio-legal studies (especially when focused on abstract philosophical debate) exaggerate their differences and impede complementarity. As such, there may well be scope for better-integrated trans-disciplinary theorization. Nevertheless, theorization again decidedly dominates the field. An important driver of the disciplines' abilities to move analysis of theory and practice forward in tandem is their capacities to identify the prospective benefits and beneficiaries of combining better theorization with improved approaches to practice.

This assertion deserves to be addressed in an expansive framework for the study of criminalization-in-practice as well as in theory. By way of illustration, nevertheless, there could be no more compelling response for benefiting prospective future youthful victims of unjust criminalization than an ambitious transnational project to bring the Age of Criminal Responsibility (ACR) into line with internationally agreed expectations. Almost all nationstates are signatories to the 1989 United Nations Convention on the Rights of the Child (UNCRC). Article 40(3) requires states to establish a minimum age "below which children shall be presumed not to have the capacity to infringe the penal law," but it "does not mention a specific age in this regard" (UN Committee on the Rights of the Child (44th session) (2007) (CRC/C/GC/10), para. 31). Minimum ACRs below the age of twelve "are considered by the Committee [of the UNCRC] not to be internationally acceptable" (para. 32).

A higher minimum of fourteen or sixteen years "contributes to a juvenile justice system which, in accordance with Article 40(3)(b) of the UNCRC, deals with children in conflict with the law without resorting to judicial proceedings" (para. 33).

The potential for reducing criminalization in practice by achieving international observance of Article 40 (as pursued by the UNCRC) is substantial. Approximately $70 \%$ of countries with registered ACRs specify a threshold at or above the age of twelve. A quarter of African countries meet the threshold, while many European and other Global North countries do not, maintaining ACRs in the age range of seven to eleven years: national wealth correlates weakly with compliance with UNCRC commitments. In the UK, the 
ACR is ten years (eight years in Scotland). The UK Children's Commissioners (2020: 43) observe that the ACR "remains very low across the UK.... [and] must be raised to at least 14." The UK Children's Commissioners (2020: 40, 41) refer to "increasing concerns about children being unlawfully deprived of their liberty" and comment that the "steadily increasing use of custodial remands is worrying." These responses should be interpreted in the context of substantial neuroscientific evidence that neural developments that determine impulse control and related behaviors continue into younger people's third decades; that there is "huge individual variability in the timing and patterning of brain development"; and, as a result, that "an arbitrary [ACR] cut-off age may not be justifiable" (Royal Society 2011: 13, 14).

The UK Children's Commissioners' responses to the UNCRC's requests continue to result in absent or insignificant advances. Better understanding of the evolving conditions under which expected ACRs of fourteen years have been achieved (or refused) offers important potential for interpreting successes and identifying obstacles. A transnational study of how activist groups, legislatures, and the public in selected countries have been persuaded to raise ACRs would present an invaluable opportunity to track strategies that have changed opinion, in anticipation of their prospective replication elsewhere. ${ }^{1}$ Ambitious though it would be, much of the initial "groundwork" for such a study could be achieved by intensive desk-studies of countries' responses to questions asked by the CRC Committee in its regular enquiries. The most important task of the ensuing analysis would then be to construct comparative assessments of obstacles that had been overcome when ACRs of fourteen years and above were initiated; of how support for them was galvanized in the face of opposition; and of the means of circumnavigating major obstacles. Countries' concerted attempts to lower ACR thresholds should also be considered. The central aim of investigation would, therefore, be to assess how (de-)criminalization-in-practice had been achieved, how it can be reproduced in diverse contexts, and how far subsequent progress could be attributed to raised ACRs.

\section{Conclusion}

How, then, has a trans-disciplinary approach to analyzing criminalization contributed to understanding how criminalization has impacted particular sections of the UK's young population? What are the implications for addressing these forms of criminalization as a practice, as well as an object of theorization? Drawing on both socio-legal and criminological scholarship, this article has synthesized aspects of these disciplines' respective analyses by focusing on three modes of criminalization. In the illegalizing mode, while socio-legal academics critiqued legislation that straddled civil and criminal law, criminologists theorized the social and economic drivers of ASB and unemployment, their implementation through policy, and their consequences. In the impelling mode, socio-legal analyses stressed young people's ignorance of prohibitions alongside compulsive acts in the face of extreme need, while criminologists charted their more specific causes "on the ground." In this mode, in particular, while adhering to their own epistemologies and methodologies, the two disciplines have been especially complementary — for example, regarding their shared interest in distinguishing between

\footnotetext{
1 In 2021, for example, Australia provided a compelling case study of the forces that typically prefigure or block change (Bucci 2021).
} 
instrumental and expressive crimes. In the imputing mode, the distinctions between them are greater. The prevailing methods for the preventative management of misconduct, which granted particular priority to the tools of risk management, "scaled" interventions and inference were more familiar terrains for criminologists than socio-legal scholars. But before these devices were deployed, socio-legal academics cautioned against excessive applications of the criminal law, inconsistent standards, and lack of proportionality. These un-synchronized transdisciplinary "overlaps" indicate mutual awareness of a prevailing need for better monitoring of the boundaries between law and policing, and better utilization of existing complementary insights as between socio-legal studies and criminology.

The exploration in the closing part of this article using trans-disciplinary analysis demonstrates how one discipline's methods and priorities has the capacity to test and illuminate the analysis offered by the other-in both cases. In such tenuous and politically charged territory, robust, triangulated trans-disciplinary interpretation achieves insights denied to mono-disciplinary analyses. Not only is there potential for further mutual reinforcement where future analyses identify it, but more importantly, trans-disciplinarity has already demonstrated its capacity to provide tangible benefits, both for practitioners who are urged to execute harsh outcomes, and for putative victims of indictments of whatever kind. The wider needs of practitioners and the on-the-ground de-construction of routine practices of criminalization suffered by the least culpable, most vulnerable young subjects both deserve greater attention. This is a hard path for practitioners to map and walk alone, and almost impossible to develop at scale. By comparison, the potential power of a prospective United Nations-supported trans-disciplinary study is one of the few possible strategic routes available for achieving transformative change and extensive benefits for vulnerable young people. Dynamic transnational interventions are now well-placed to move beyond the dayto-day struggles of committed professionals and dedicated activists: such interventions hold out important capacities to turn the tide of criminalization that is tolerated in nationstates that refuse to observe agreed-upon international standards for the age of criminal responsibility.

Acknowledgments I am most grateful to two anonymous reviewers, and to Deborah Drake and Steve Tombs (Department of Social Policy and Criminology, The Open University, UK) for suggesting substantive improvements to an earlier version of this piece.

Funding The author did not receive support from any organization for the submitted work. No funding was received to assist with the preparation of this manuscript. No funding was received for conducting this study. No funds, grants, or other support was received. The author has no relevant financial or non-financial interests to disclose.

\section{Declarations}

Conflict of interest The author has no conflicts of interest to declare that are relevant to the content of this article. The author certifies that he has no affiliations with or involvement in any organization or entity with any financial interest or non-financial interest in the subject matter or materials discussed in this manuscript. The author has no financial or proprietary interests in any material discussed in this article.

Open Access This article is licensed under a Creative Commons Attribution 4.0 International License, which permits use, sharing, adaptation, distribution and reproduction in any medium or format, as long as you give appropriate credit to the original author(s) and the source, provide a link to the Creative Commons licence, and indicate if changes were made. The images or other third party material in this article are included in the article's Creative Commons licence, unless indicated otherwise in a credit line to the material. If material is not included in the article's Creative Commons licence and your intended use is not permitted by statutory regulation or exceeds the permitted use, you will need to obtain permission directly from the copyright holder. To view a copy of this licence, visit http://creativecommons.org/licenses/by/4.0/. 


\section{References}

Ashworth, A., \& Zender, L. (2010). Preventive Orders: A Problem of Under Criminalization? In Duff, R., Farmer, L., Marshall, S., Renzo, M., \& Tadros, V. (Eds.) The Boundaries of the Criminal Law (pp.5987). Oxford: Oxford University Press.

Barnes, R.A. (1895). Economic Causes of Crime. Madison, WI: University of Wisconsin-Madison.

Baron, S. (2008). Street Youth, Unemployment, and Crime: Is it that Simple?. Canadian Journal of Criminology and Criminal Justice, 50(4), 399-434.

Bateman, T. (2011). Punishing Poverty: The Scaled Approach and Youth Justice Practice. The Howard Journal of Criminal Justice, 50(2), 171-183.

Beckett, K., \& Western, B. (2001). Governing social marginality: welfare, incarceration, and the transformation of state policy. Punishment and Society, 3(1), 43-59.

Box, S. (1983). Crime, Power and Mystification, London: Tavistock.

Bucci, N. (2021). Agreement to raise Australia's age of criminal responsibility to 14 unlikely as states go own way. The Guardian, April 15. Retrieved on February 1, 2022, from https://www.theguardian.com/law/2021/apr/16/agreement-to-raise-australias-age-of-criminal-responsibility-to-14-unlik ely-as-states-go-own-way.

Carlen, P. (1996). Jigsaw: A Political Criminology of Youth Homelessness. Buckingham, UK, and Bristol, PA: Open University Press.

Carmichael, F., \& Ward, R. (2000). Youth Unemployment and Crime in The English Regions and Wales. Applied Economics, 32(5), 559-71.

Chadwick, K., \& Scraton, P. (2013). Criminalisation. In McLaughlin, E., \& Muncie, J. (Eds.) The Sage Dictionary of Criminology (3rd edition) (pp.102-104). London: Sage.

Crawford, A. (2009). Governing Through Anti-Social Behaviour: Regulatory Challenges to Criminal Justice. The British Journal of Criminology, 49(6), 810-831.

Currie, E. (1996). Missing Pieces: Notes on Crime, Poverty, and Social Policy. Critical Criminology: An International Journal, 7(1), 37-52. https://doi.org/10.1007/BF02461093.

Erikson, E.H. (1962). Youth: Fidelity and Diversity. Daedalus, 117(3), 1-24.

Farrington, D. (2007). Childhood Risk Factors and Risk-Focused Prevention. In Maguire, M., Morgan, R., \& Reiner, R. (Eds.) Oxford Handbook of Criminology, (4th edition) (pp.602-40). Oxford: Oxford University Press.

Fergusson, R. (2013). Risk, Responsibilities and Rights: Reassessing the Economic Causes of Crime Thesis in a Recession. Youth Justice, 13(1), 31-56.

Fletcher, D. (2016). First Wave Findings: Offenders. Retrieved on September 27, 2021, from http://www. welfareconditionality.ac.uk/wp-content/uploads/2016/05/WelCond-findings-offenders-May16.pdf.

Garthwaite, K. (2016). Hunger Pains: Life Inside Foodbank Britain. Bristol, UK: Policy Press.

Godfrey, C., Bradshaw, J., \& Hutton, S. (2002). Estimating the Cost of Being "Not in Education, Employment or Training” at Age 16-18. London: Department for Education and Skills.

Goldson, B., \& Muncie, J. (2006). Rethinking Youth Justice: Comparative Analysis, International Human Rights and Research Evidence. Youth Justice, 6(2), 91-106.

Goodey, J. (2001). The Criminalisation of British Asian Youth: Research from Bradford and Sheffield. Journal of Youth Studies, 4(4), 429-450.

Gray, P., \& Smith, R. (2019). Governance Through Diversion in Neoliberal Times and the Possibilities for Transformative Social Justice. Critical Criminology: An International Journal, 27(4), 575-90. https://doi.org/10.1007/s10612-019-09475-3

Griggs, J., \& Evans, M. (2010). Sanctions Within Conditional Benefit Systems: A Review of Evidence. York, UK: Joseph Rowntree Foundation.

Haines, K., \& Case, S. (2012). Is the Scaled Approach a Failed Approach? Youth Justice, 12(3), $212-28$.

Harradine, S., Kodz, J., Lemetti, F., \& Jones, B. (2004). Defining and Measuring Anti-Social Behaviour. London: Home Office.

House of Commons (2009). Young People Not in Education, Employment or Training. London: House of Commons. Retrieved on September 27, 2021, from https://publications.parliament.uk/pa/cm200 910/cmselect/cmchilsch/316/316ii.pdf.

Husak, D. (2008). Overcriminalisation: The Limits of the Criminal Law. Oxford, UK: Oxford University Press.

International Labor Organization (2013). Global Trends for Youth 2013: A Generation at Risk. Geneva: ILO. Jennings, W., Farrall, S., \& Bevan, S. (2012). The Economy, Crime and Time: An Analysis of Recorded Property Crime in England and Wales, 1961-2006. International Journal of Law, Crime and Justice, 40(3), 192-210. 
Kadish, S. (1967). The Crisis of Overcriminalization. The Annals of the American Academy of Political and Social Science, 374(1), 157-170.

Lemert, E.M. (1951). Social Pathology. New York: McGraw Hill.

Muncie, J. (2008). The Theory and Politics of Criminalisation. Criminal Justice Matters, 74(1), $13-14$.

Muncie, J. (1999, 2021). Youth and Crime (First/Fifth Editions). London: Sage

National Centre for Social Research (2011). The August Riots in England: Understanding the Involvement of Young People. London: NCSR.

Newburn, T. (2015). The 2011 England Riots in Recent Historical Perspective. The British Journal of Criminology, 55(1), 39-64.

Oxford English Dictionary Online (2019). “Criminalize.” Retrieved on December 2, 2021, from www.oxfor ddictionaries.com.

Platt, A.M. (1977). The Child Savers: The Invention of Delinquency. Chicago, IL: The University of Chicago Press.

Quinney, R. (1977). Class, State, and Crime. New York: Longman.

Reiman, J., \& Leighton, P. (1979/2017). The Rich Get Richer and the Poor Get Prison: Ideology, Class, and Criminal Justice. New York: Routledge.

Royal Society (2011). Neuroscience and the Law. London: The Royal Society.

Scraton, P. (2007). Power, Conflict and Criminalisation. Abingdon, Oxon, UK: Routledge.

Simester, A., \& Von Hirsch, A. (2011). Crimes, Harms and Wrongs: On the Principles of Criminalisation. Oxford, UK: Hart Publishing.

Selman, K., Myers, R., \& Goddard, T. (2019). Young People, Shadow Carceral Innovations, and the Reproduction of Inequality. Critical Criminology: An International Journal, 27(4), 527-42. https://doi.org/ 10.1007/s10612-019-09468-2.

Social Mobility and Child Poverty Commission (2014). State of The Nation 2014: Social Mobility and Child Poverty in Great Britain. London: HMSO.

Somavia, J. (2012). Director-General's address to the plenary of the $101^{\text {st }}$ International Labor Conference. June 6. Geneva: International Labor Organization. Retrieved on February 1, 2022, from http://www. ilo.org/global/about-the-ilo/media-centre/statements-and-speeches/WCMS_182362/lang--en/index. htm

Spitzer, S. (1975). Toward a Marxian Theory of Deviance. Social Problems, 22(5), 638-51.

Squires, P. (1990) Anti-Social Policy: Welfare, Ideology and the Disciplinary State. Hemel Hempstead: Harvester Wheatsheaf.

Squires, P. (Ed.) (2008). ASBO Nation: The Criminalisation of Nuisance. Bristol, UK: Policy Press.

Squires, P., \& Lea, J. (Eds.) (2012). Criminalisation and Advanced Marginality: Critically Exploring the Work of Lö̈c Wacquant. Bristol, UK: Policy Press.

Tadros, V. (2008). Crimes and Security. The Modern Law Review, 71(6), 940-70.

Tinson, A., Ayrton, C., Barker, K., Born, T.B., Aldridge, H., \& Kenway, P. (2016). Monitoring Poverty and Social Exclusion 2016. York, UK: Joseph Rowntree Foundation.

Tombs, S. (2005). Corporate Crime. In Hale, C., Hayward, K., Wahidin, A., \& Wincup, E. (Eds.), Introducing Crime and Criminology (pp.267-288). Oxford, UK: Oxford University Press.

Tomlin, P. (2013). Extending the Golden Thread? Criminalisation and the Presumption of Innocence. Journal of Political Philosophy, 21(1), 44-66.

Tyler, I. (2013). Revolting Subjects: Social Abjection and Resistance in Neoliberal Britain. London: Zed Books.

UK Children's Commissioners (2020). Report of the Children's Commissioners of the United Kingdom of Great Britain and Northern Ireland to the United Nations Committee on the Rights of the Child. London: UK Children's Commissioners. Retrieved on February 1, 2022, from https://www.childrensc ommissioner.gov.uk/report/report-to-the-united-nations-committee-on-the-rights-of-the-child/.

UK Parliament (2013). 'Anti-social Behaviour, Crime and Policing Bill, 2013', London, Stationery Office. Retrieved on February 1, 2022, from https://publications.parliament.uk/pa/bills/lbill/2013-2014/0066/ 14066.pdf.

Watts, B., Fitzpatrick, S., Bramley, G., \& Watkins, D. (2014). Welfare Sanctions and Conditionality in the $U K$. York, UK: Joseph Rowntree Foundation.

Webster, C. (1997). The Construction of British 'Asian' Criminality. International Journal of the Sociology of Law, 25(1), 65-86.

West, D.J., \& Farrington, D. (1973). Who Becomes Delinquent? London: Heinemann.

Youth Justice Board for England and Wales (2010). Youth Justice: The Scaled Approach. London: YJB.

Publisher's Note Springer Nature remains neutral with regard to jurisdictional claims in published maps and institutional affiliations. 